\title{
DIGITAL LITERACY AS A SOLUTION TO IMPROVE THE QUALITY OF INDONESIA'S HUMAN RESOURCES
}

\author{
Danang Dwi Harmoko \\ Bina Sarana Informatika University, Indonesia \\ Danang.dnd@bsi.ac.id
}

\begin{abstract}
Received: 13 Juli $2021 \quad$ The Indonesian literacy index in 2020 is still low, to be precise at 0.54. Revised: 02 September 2021 Even though literacy skills, especially in the digital field, are an important Accepted: 02 September 2021 component in facing challenges in the future. Therefore, various efforts are needed to increase the national digital literacy index. This study aims to provide an overview of the importance of digital literacy education to improve the quality of human resources to face the demographic bonus in 2030-2040. This study used a qualitative descriptive method, while the data were taken from various literature sources, both print and online. The result of this research is that digital literacy education is very important for improving the quality of Indonesia's human resources. Individuals who have digital literacy will have certain characteristics, such as 1) the ability to use digital potential maximally, 2) digital resilience, 3) become positive and productive individuals, and 4) become part of the world community
\end{abstract}

Keywords: Digital literacy, Human Resource Quality, Education

(*) Corresponding Author: $\quad$ Harmoko, Danang.dnd@ bsi.ac.id, 085781435458

How to Cite: Harmoko, D. D. (2021). Digital Literacy As A Solution To Improve The Quality Of Indonesia's Human Resources. Research and Development Journal of Education, 7 (2), 413-423.

\section{INTRODUCTION}

Digital plays an important role in human interaction in society. Almost every individual has a dependency with technology. This phenomenon occurs in almost all over the world, including Indonesia, which is a developing country with a fairly rapid growth in internet users (Mujiyana \& Elissa, 2013). The average Indonesian spends nearly 8 hours surfing the internet (Kemp, 2020). Especially on social media, they spend an average of 3 hours 26 minutes (Kemp, 2020). This reflects that people's social life is very dependent on the internet. Almost every aspect of life experiences digital technology intervention, especially socio-economics (Pagani \& Pardo, 2017).

Since its emergence, digital technology has slowly shifted conventional human relationship patterns and formed new social interaction patterns and systems based on digital ((Olsson et al., 2020). Furthermore, social media has now become a new space for social interaction in human life (Bjornestad et al., 2020). Its existence, which allows conversations to be carried out without knowing space and time, has become a new arena for questioning opinions, ideas, and battles and issues (Back et al., 2019). So that the high number of internet penetration requires its users to adjust themselves so that social values do not degrade.

Digital literacy is an important piece in realizing order in relations between citizens both in cyberspace and in the real world. The fact is that technological progress has not been matched by the social adaptability of society. This is reflected in the emergence of negative phenomena on social media such as cyber bullying (Hee et al., 2018), buzzers (Indah \& Zuhdy, 2018), hoaxes ((Park \& Rim, 2020), social climbing (Fathoni, 2019), and various new crimes that have emerged from digital (Curiel et al., 2020). 
Report from the statistical survey institute, internet users in Indonesia in 2020 are dominated by the age range 18-24 years, namely as much as 35\% (Nurhayati-Wolff, 2020). This shows that the millennial generation who still intersects with school is very involved in social interaction in cyberspace (Willems et al., 2019). They are not only involved in topic conversations about teenage but are also concerned with social, economic, political and environmental issues (Nur, 2020).

On the one hand, this is a good sign because with all the advantages the millennial generation has, both in terms of physicality, energy, and the ability to think that better mastery ability will be a positive asset for future career development. The realization has begun to be seen from the emergence of startups pioneered by millennials. In Indonesia, there are quite a number of successful startups such as Gojek, Tokopedia, Bukalapak, and so on in various fields.

On the other hand, the rise of cyberbullying, hate speech, and moral degradation is a negative effect of the high intensity of internet use. Therefore, provisioning efforts related to digital literacy through various channels is very important (Santos \& Serpa, 2017). One of the digital literacy extension channels is through classrooms. The prerequisite for the success of digital literacy education is collaboration between stakeholders (Santos \& Serpa, 2017). The government through the education ministry as the regulator needs to formulate policies that emphasize the importance of including digital literacy into higher education units and are taught to students. The next step is for the head and staff under him to formulate a curriculum and learning materials.

Indonesia is currently preparing to face a demographic bonus in the period 20302040 (Bappenas, 2020) in which the number of productive age population (15-64 years) is greater than the number of unproductive people. When viewed from this age range, the younger generation, namely 15-35 years of age, strategic steps are needed to prepare the Indonesian population of children with a variety of provisioning both cognitive aspects and other life skills without eliminating the Indonesian national identity with its social values and structure (Minan, 2021). The demographic bonus has two opposing sides depending on the government and society reacting to it. Good handling such as preparing various programs both short and long term to optimize the demographic bonus (Subandowo, 2017). The program should aim to form Indonesian people who are superior in terms of mastery of technology and science and have the personality that is needed in the future.

One of the steps the government has taken is the implementation of the "Merdeka Belajar" program. This program is an effort initiated by the government to overcome the low absorption of industry towards the workforce of higher education graduates in Indonesia (Siregar et al., 2020). This is because the school curriculum does not link and match the needs of the industrial world. Therefore, this program is designed to shorten the gap. Students are given more portion of experience-based learning by directly joining the industrial. The goal is to make students understand the real conditions of the working world. Furthermore, the estuary of this program is to prepare and build human resources to welcome a golden Indonesia in 2045 (Wahdani \& Burhanuddin, 2020).

Indonesian education has considerable challenges, such as quality disparities between regions, infrastructure, teacher quality, to the determination of the changing education system policies that seem short-term (Syamsuar \& Reflianto, 2019). This condition was exacerbated by the COVID 19 pandemic which forced massive changes in teaching methods in classrooms to digital spaces (Aji, 2020). If we look further, these changes do not only have a technical impact but also require changes in behavior, attitudes, and mindsets. This impact has received less attention from the government and society. The government only focuses on preparing information technology infrastructure so that teaching and learning activities continue as usual. This is reflected in the creation 
of an emergency curriculum which includes the flexibility of the school education unit in determining methods, content, and technical teaching and learning interactions.

The human development index in 2020 is in the range of 0.54 , which means that a child born in Indonesia at this time will only reach 54 percent of their maximum productivity if they meet the comprehensive education and health benchmarks which place Indonesia in the 111th rank out of 189 countries (Bank, 2019). This shows that Indonesia is still far behind other countries in the quality and quality of human resources. Therefore, efforts are needed to increase the human development index, one of which is through digital literacy.

Through the above explanation, it can be assumed that the importance of providing digital literacy to the younger generation in higher education is to improve the quality of human resources.

\section{METHODS}

This research is a qualitative descriptive research in which the data collection process uses the library research method. The descriptive method is a fact-finding method with the correct interpretation because this method is used to create a picture of a situation or activity (Nazir, 1985). The type of research that is suitable for this method is discourse or phenomenon analysis and does not test hypotheses. Sources of data used are obtained through various written sources including books, research results, articles, or websites that are relevant and synergistic with the issues discussed (Wirartha, 2006).

The data collected is then analyzed in relation to the problems raised in this study. The results of the analysis are presented in the form of a descriptive description. The steps taken in this research method are, 1) selecting and determining the problem to be studied, 2) conducting library observations by looking for and studying relevant research, 3) looking for other supporting data that can help reveal the current phenomenon. researched, 4) compile and analyze various sources obtained descriptively in order to make it easier for readers to understand the findings in this study.

\section{RESULTS \& DISCUSSION}

\section{Digital Literacy in Indonesia}

Digital literacy is the ability to understand and use information in various formats from multiple sources when presented via computers and, in particular, through the internet (Knobe \& Lankshear, 2006). Another opinion was expressed by Gentikow, 2015, which states that the meaning of digital literacy is the use of digital technology, communication tools and or networks to access, manage, integrate, evaluate, and make information so that it can function as public knowledge. In other words, digital literacy concerns the ability to adapt both operationally, functionally, to technology and still being able to maintain social values. Operational ability is the basic ability of digital literacy where a person understands how technology works. Why operational ability is a basic ability, this is because at this level one only knows technology. The next level is functional abilities where a person does not only know and know how a technological system works but also understands its functions and benefits. The last level is social skills where in addition to understanding how a person works and functions at this level, he is able to add social values that exist in society.

A survey conducted by Indonesian Ministry of Information and Communication which was conducted in November 2020 in 34 provinces in Indonesia stated that the 
digital literacy level of internet users is still low. The survey sample was taken from 18-31 August 2020 using multi-stage random sampling with the home visit technique. Total number of respondents: 1670 people. Margin of Error $\pm 2.45 \%, 95 \%$ confidence level. Respondents are household members aged 13-70 years and have accessed the internet in the last 3 months. The validity and reliability test were conducted on August 11, 2020. The low level of digital literacy can be seen from the many problems caused by a lack of digital literacy, such as 1,064,000 immoral content, 233,000 gambling, and 10,700 content fraud (Kominfo, 2020).

\subsection{Sources of frequently accessed information}

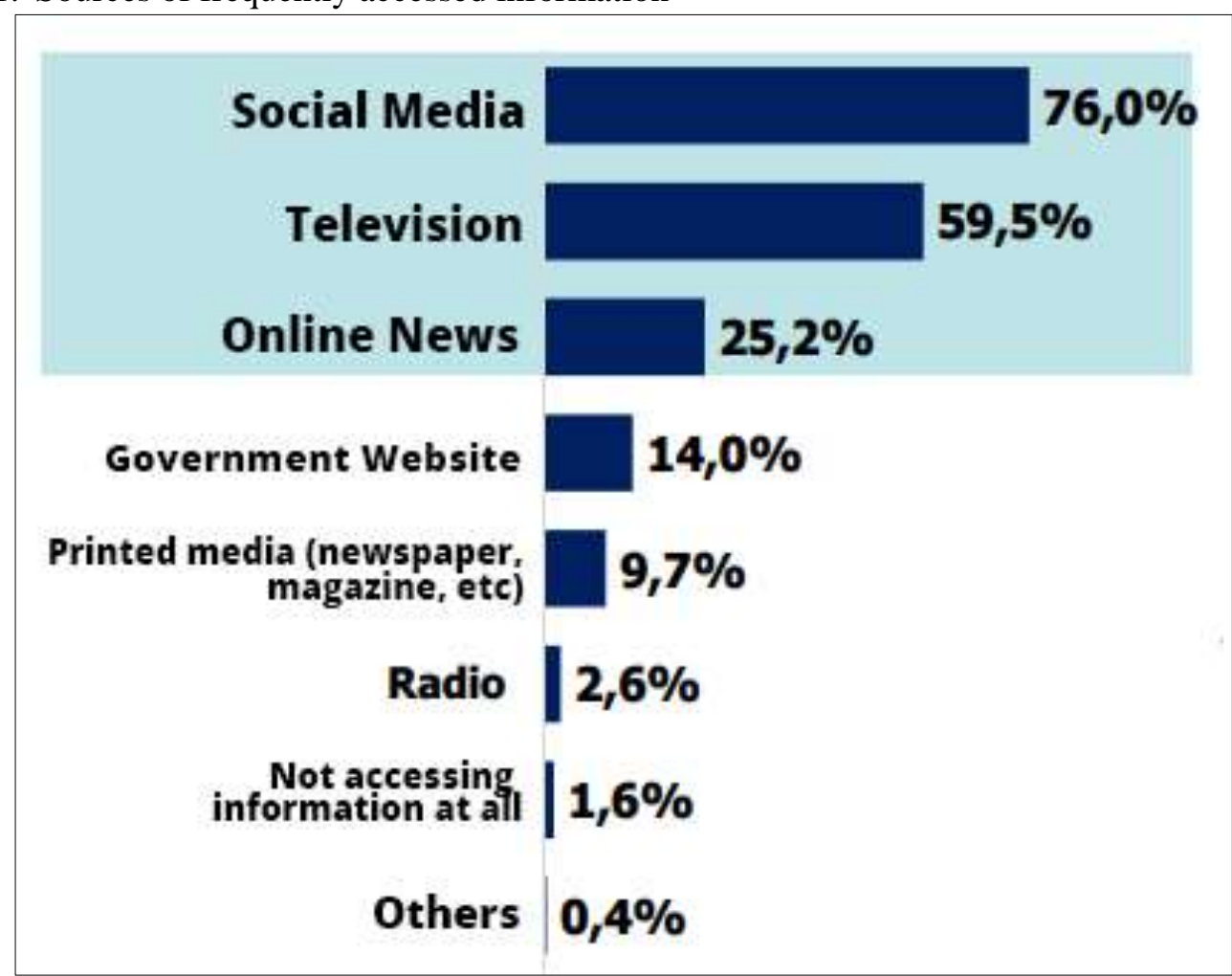

Figure 1.

Media sources frequently accessed in Indonesia Resource: Kominfo (2020)

From Figure 1 above, it can be concluded that social media is the source of information most frequently accessed by Indonesian teenagers. Social media as a platform that allows the dissemination and acquisition of information to be carried out by anyone regardless of its credibility (Kim et al., 2014). On the one hand, this makes information spread faster and more diverse both in terms of content and perspectives. The user has more choices about which information to absorb. But on the other hand, this also creates a high amount of disinformation on social media. This is a real consequence of the absence of filtering information from social media. Therefore, it requires the role of the government, society, and education personnel to educate the use of social media properly. 
1.2. Information and risk habits on social media

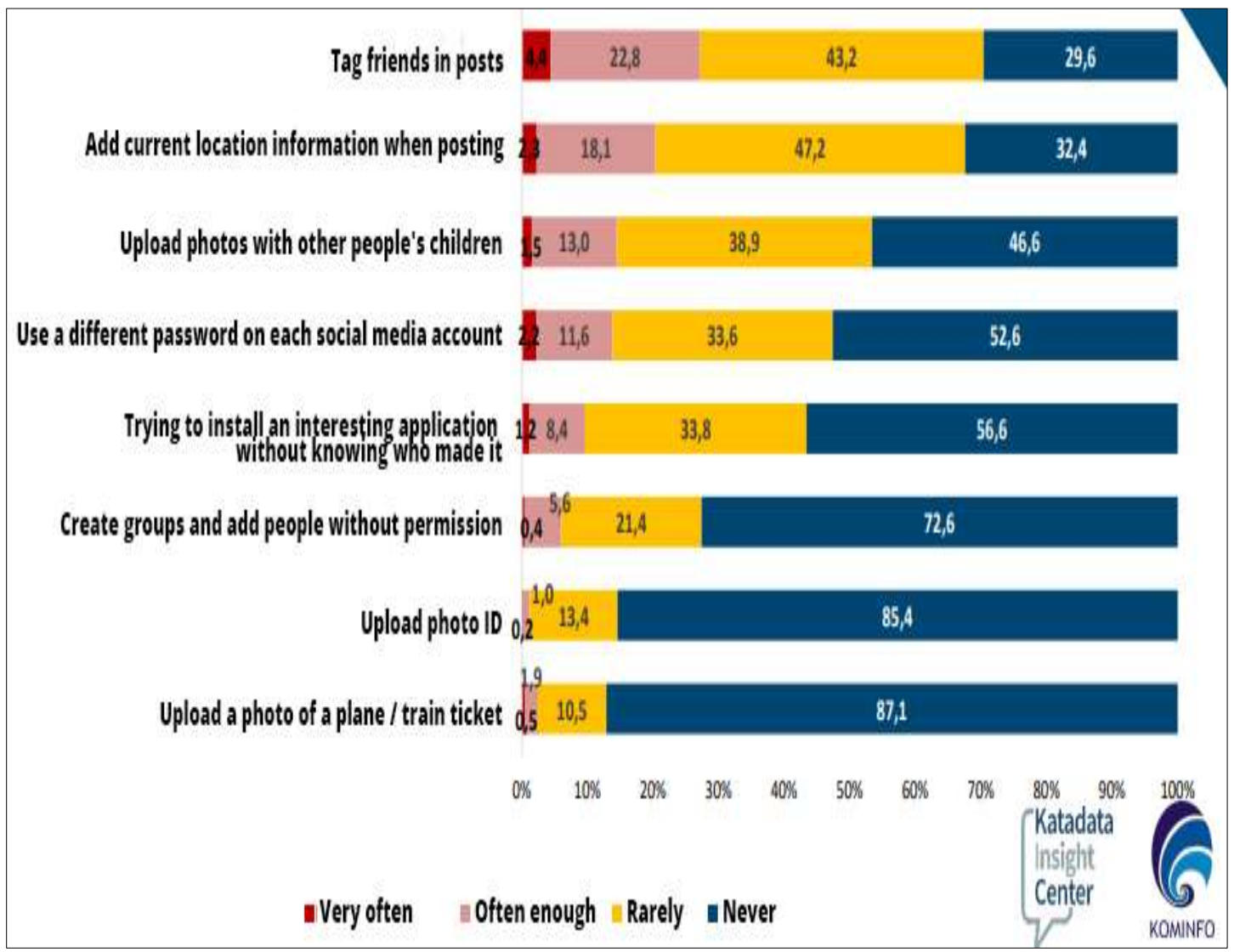

Figure 2.

Information and risk habits on social media

Resource: Kominfo (2020)

Figure 2 above shows that awareness regarding digital security is at the middle level. This shows that the Indonesian people have started to understand the importance of digital security literacy. However, not a few social media users still do not understand the importance of personal data security. This can be seen from the high number of uploading personal information on social media such as photo ID cards, plane or train tickets that contain data on names, dates of birth, home addresses, and telephone numbers. 


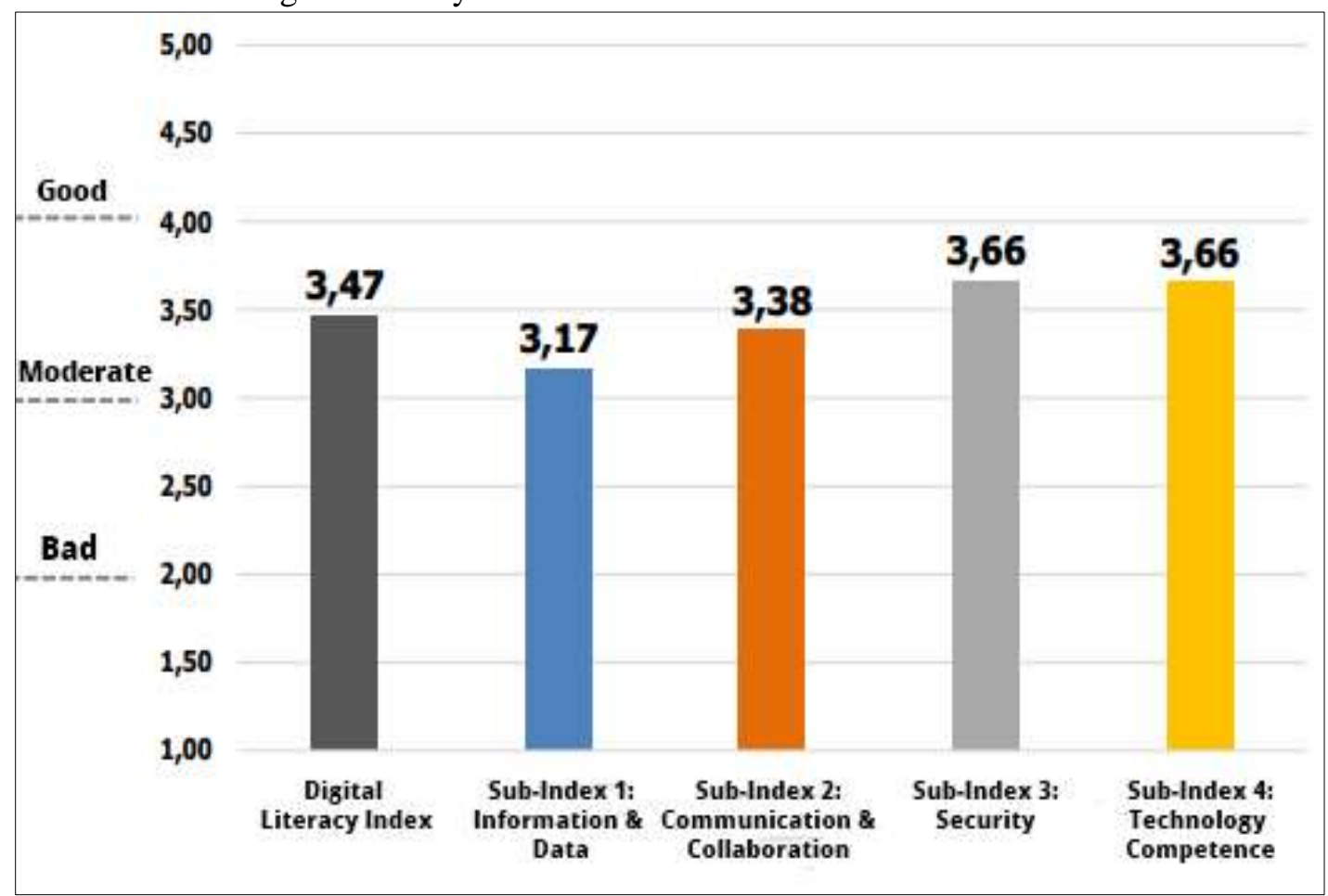

Figure 3.

Indonesian digital literacy index in 2020

Resource: Kominfo (2020)

Figure 3 above shows that Indonesia's digital literacy index in 2020 is 3.47 or at the "medium" level. Meanwhile, the information \& data literacy sub-index was 3.17. Communication \& collaboration sub-index of 3.38. The security sub-index is 3.66 . The technology capability sub-index was 3.66.

From the data above, literacy towards information and data ranks the lowest. This causes high levels of disinformation and the spread of hoaxes in the community through social media. In addition, the ability to read data also requires more attention from the government. Reading data is an important skill in order to understand and use data for the intended purpose. In addition, the ability to read data can also prevent a person from fraud and hoaxes.

2. The importance of digital literacy to improve the quality of human resources

2.1. Digital literacy learning

In 2016, the Ministry of Education and Culture launched a national literacy program. This is an effort to increase national literacy. One form of realization is the creation of a book "Guidelines for the National Literacy Movement" which contains a roadmap for the implementation of literacy training in educational units. In this guidebook, there are 6 dimensions of literacy (reading and writing, numeracy, science, digital, finance, and culture and citizenship). Digital literacy is defined as knowledge and skills to use digital media, communication tools, or networks to find, evaluate, use, create information, and utilize it in a healthy, wise, intelligent, thorough, precise, and law-abiding manner in order to foster communication and interaction in everyday life (Kementerian Pendidikan dan Kebudayaan, 2017). There are 3 domains of the national literacy movement, namely school, family and community. Literacy in 
schools is carried out by integrating it with curricular, co-curricular and extracurricular activities. The implementation can be done inside the classroom or outside the classroom which is supported by parents and the community (Kementerian Pendidikan dan Kebudayaan, 2017).

Digital literacy in schools is literacy learning whose activities are mostly carried out in schools involving students, teachers, and parents. This activity is carried out by displaying good practices about literacy and making it a habit and culture in the school environment. Digital literacy is integrated into teaching and learning activities in schools so that it becomes an inseparable part of all series of student and educator activities, both inside and outside the classroom. Educators have a moral obligation to be role models in literacy. Digital literacy involves public participation, such as literacy activists, parents, community leaders, and professionals. The success of literacy in schools needs to be pursued through activities that foster a culture of literacy.

1) Capacity Building for Facilitators

a. Training of teachers and education personnel in applying literacy to learning;

b. Training of teachers and education personnel in making literacy-based educational games; and

c. Discussion forum for school residents to develop literacy activities and increase literacy skills.

2) Increasing the number and variety of quality reading sources

a. Provision of various non-learning reading materials;

b. Provision of teaching aids and educational toys that support literacy activities;

c. Provision of literacy learning materials in digital form; and

d. Book writing program for students, teachers, and education personnel.

3) Expanding Access to Learning Resources and Coverage of Learning Participants

a. Development of supporting facilities that form a literacy-rich ecosystem;

b. Provision of laboratories related to literacy, for example, language, science, financial and digital laboratories;

c. Provision of reading corners, both in each class and in strategic places in schools;

d. Optimization of school libraries;

e. Organizing open houses by schools that have developed literacy;

f. School scrutiny program; and

g. Implementation of literacy campaigns.

4) Increasing Public Engagement

a. Conducting discussion sessions with figures or activists in various fields of literacy regarding their experiences and knowledge related to the fields they are good at;

b. Implementation of literacy festivals or months involving experts, literacy activists, and the general public; and

c. BUMN and DUDI involvement in the procurement of reading materials and literacy activities in schools

5) Strengthening Governance

a. Allocating specific time or schedules for carrying out various literacy activities in schools;

b. Allocation of budgets to support literacy in schools;

c. The formation of a school literacy team consisting of school principals, supervisors, teachers, and representatives of parents of students with the task of monitoring the progress of literacy activities in schools; 
d. Making policies that regulate literacy activities in schools so as to maximize the involvement of all school members; and

e. Strengthening the role of the school committee to build cooperative relationships and commitment in carrying out literacy activities.

2.2. Digital Literacy Indicators in Schools

Digital literacy learning activities in schools need to be well prepared based on the following indicators.

1) Class Base

a. Number of digital literacy trainings attended by principals, teachers, and education personnel;

b. The intensity of the application and use of digital literacy in learning activities; and

c. The level of understanding of principals, teachers, education staff, and students in using digital media and the internet.

2) Basis of School Culture

a. The number and variety of digital-based reading materials and props;

b. Frequency of borrowing digital themed books;

c. The number of activities in schools that utilize technology and information;

d. The number of school information presentations using digital media or web sites;

e. Number of school policies regarding the use and utilization of information and communication technology in the school environment; and

f. The level of utilization and application of information and communication and communication technology in terms of school services (for example, report cards, financial management, student data utilization, school profiles, etc.)

2.3. The link between strengthening digital literacy and improving the quality of human resources

Efforts to improve the quality of human resources can be done in various ways. Strengthening literacy is one way to improve the quality of Indonesian people in facing the competition in the digital era. Here are some of the benefits a person can get from mastering digital literacy.

1) Maximum Use and Utilization

Technical recognition and understanding of technology enables users to make the most of it for their intended purpose. For example, understanding the functions of search engines will make it easier for someone to find the information needed,

2) Digital Resilience

Digital resilience is understanding when you might be at risk online, knowing what to do if something goes wrong, learning from experience, and being able to form self-defense against the negative effects of the internet. Digital resilience is born out of good literacy about how the internet works and how it impacts personal and social life.

3) Positive and Productive Personal

A good understanding of digital literacy will enable someone to map potential and threats in the online world. This will make you focus more on potential and avoid negative impacts. The implication is an increase in one's productivity.

4) Part of Global Citizen

5) The internet has boundaries between countries in the world. The difference between distance and time seems insignificant when everyone is connected to the internet. The consequence is the creation of digital norms and values that are 
mutually agreed upon throughout the world, such as the principles of universality, gender equality, tolerance and respect for human rights. The role of digital literacy will help accelerate Indonesia to become part of the world community.

\section{CONCLUSION}

Strengthening digital literacy in Indonesia plays an important role for the progress of the nation. This is because almost every activity we do is related to the digital world. In addition, the need for implementing this program nationally through school education units is also based on the fact that Indonesia's digital literacy index is still low at 0.54. This condition has implications for the lagging quality of Indonesian human resources compared to other countries, especially in the Southeast Asia region. To respond to this, Indonesia implements the "National Literacy Movement" program which is derived from various elements of society, one of which is incorporating literacy learning into the educational curriculum.

The main focus of digital literacy learning activities in schools is to foster a literacy culture. To achieve this goal, several supporting factors are needed, including strengthening the capacity as a facilitator, increasing the number and variety of quality reading sources, expanding access to learning resources and coverage of learning participants, increasing public involvement, and strengthening governance. Collaboration between national education stakeholders starting from the government to the smallest unit, namely the family is very important so that these factors can go hand in hand and be able to play their function optimally. Then, to measure the level of success, it can be seen through 2 indicators, namely the basis of class and the basis of school culture.

A digital literacy program that runs well will form a superior national generation. Individuals who already have an understanding of digital literacy will have several characteristics, including 1) being able to use technology and maximizing its benefits, 2) having digital resilience, 3 ) being a person who has positive and productive behavior in the digital world, 4) being part of the world community. Therefore, this program must be well managed from planning to monitoring and evaluation. Digital literacy education must be an integral part of the curriculum in every education unit considering its important role in protecting the nation's generation from the negative effects of the digital world.

\section{REFERENCES}

Aji, R. H. S. (2020). Dampak COVID-19 pada pendidikan di indonesia: Sekolah, keterampilan, dan proses pembelajaran. Salam: Jurnal Sosial Dan Budaya Syar-I, 7(5), 395-402.

Back, E. A., Back, H., \& Freden, A. (2019). A social safety net? Rejection sensitivity and political opinion sharing among young people in social media. New Media \& Society, 21(1), 298-316.

Bank, T. W. (2019). Seri Pengetahuan Modal Manusia Indonesia. The World Bank. https://www.worldbank.org/in/country/indonesia/brief/indonesia-human-capital

Bappenas. (2020). Bonus Demografi 2030-2040: Strategi Indonesia Terkait Ketenagakerjaan Dan Pendidikan. Bappenas. https://www.bappenas.go.id/files/9215/0397/6050/Siaran_Pers__Peer_Learning_and_Knowledge_Sharing_Workshop.pdf

Bjornestad, J., Moltu, C., Veseth, M., \& Tjora, T. (2020). Rethinking social interaction: 
Empirical model development. Journal of Medical Internet Research, 22(4).

Curiel, R. P., Cresci, S., Muntean, C. I., \& Bishop, S. R. (2020). Crime and its fear in social media. Palgrave Commun, 6(57). https://doi.org/https://doi.org/10.1057/s41599-020-0430-7

Fathoni, N. A. (2019). Perilaku Komunikasi Panjat Sosial Di Kalangan Mahasiswa (Studi Fenomenologi Pada Perilaku Komunikasi Panjat Sosial Di Kalangan Mahasiswa Kota Bandung). Universitas Komputer Indonesia.

Gentikow, B. (2015). The role of media in developing literacies and cultural techniques. Nordic Journal of Digital Literacy, 35-52.

Hee, C. Van, Jacobs, G., Emmery, C., Desmet, B., Lefever, E., \& Verhoeven, B. (2018). Automatic detection of cyberbullying in social media text. PLOS ONE, 13(10). https://doi.org/https://doi.org/10.1371/journal.pone.0203794

Indah, R. N., \& Zuhdy, H. (2018). Features of Indonesian Media Buzzer on Islamic Issues. 1st Annual International Conference on Language, Literature and Media (AICOLLIM).

Kementerian Pendidikan dan Kebudayaan. (2017). Panduan Gerakan Literasi Nasional.

Kemp, S. (2020). Digital 2020: Indonesia. Hotsuite \& We Are Social. https://datareportal.com/reports/digital-2020-indonesia

Kim, K.-S., Sei-Ching Joanna Sin, A., \& Yoo-Lee, E. Y. (2014). Undergraduates' Use of Social Media as Information Sources. College \& Research Libraries, 75(4), 442457.

Knobe, M., \& Lankshear, C. (2006). Digital literacy and digital literacies: Policy, pedagogy and research considerations for education. Nordic Journal of Digital Literacy, $1(1), 12-24$.

Kominfo. (2020). Status Literasi Digital Indonesia: Survei di 34 Provinsi pada November 2020. Kominfo. https://aptika.kominfo.go.id/wp-content/uploads/2020/11/SurveiLiterasi-Digital-Indonesia-2020.pdf

Minan, A. K. (2021). Manajemen Pendidikan Islam dan Penyiapan Bonus Demografi Indonesia Tahun 2045. Islamic Management: Jurnal Manajemen Pendidikan Islam, 4(1), 116-131.

Mujiyana, \& Elissa, I. (2013). Analisis Faktor-Faktor yang Mempengaruhi Keputusan Pembelian Via Internet Pada Toko Online. J@ TI Undip: Jurnal Teknik Industri, $8(3), 143-152$.

Nazir, M. (1985). Metode Penelitian (Cetakan ke-1) (1st ed.). Ghalia Indonesia.

Nur, E. (2020). Tanggapan Generasi Z Terhadap Pemanfaatan Media Sosial Dalam Mendukung Keterlibatan Dalam Pemilu Legislatif 2019. Jurnal Penelitian Pers Dan Komunikasi Pembangunan, 24(2), 117-131.

Nurhayati-Wolff, H. (2020). Breakdown of social media* users by age and gender in Indonesia as of 2020. https://www.statista.com/statistics/997297/indonesia-breakdown-social-mediausers-age-gender/

Olsson, T., Jarusriboonchai, P., Woźniak, P., Paasovaara, S., Väänänen, K., \& Lucero, A. (2020). Technologies for enhancing collocated social interaction: review of design solutions and approaches. Computer Supported Cooperative Work, 29(1), 29-83.

Pagani, M., \& Pardo, C. (2017). The Impact of Digital Technology on Relationships in a Business Network. Industrial Marketing Management, 67, 185-192.

Park, K., \& Rim, H. (2020). "Click First!": The Effects of Instant Activism Via a Hoax on Social Media. Social Media+ Society, 6(2).

Santos, A. I., \& Serpa, S. (2017). The Importance of Promoting Digital Literacy in Higher Education. International Journal of Social Science Studies. International Journal of Social Science Studies, 5(6). 
Siregar, N., Sahirah, R., \& Harahap, A. A. (2020). Konsep Kampus Merdeka Belajar di Era Revolusi Industri 4.0. Fitrah: Journal of Islamic Education, 1(1), 141-157.

Subandowo, M. (2017). Peradaban dan Produktivitas dalam Perspektif Bonus Demografi serta Generasi Y dan Z. SOSIOHUMANIKA, 10(2), 191-208.

Syamsuar, \& Reflianto. (2019). Pendidikan dan tantangan pembelajaran berbasis teknologi informasi di era revolusi industri 4.0. E-Tech: Jurnal Ilmiah Teknologi Pendidikan, 6(2).

Wahdani, F., \& Burhanuddin, H. (2020). Pendidikan Keluarga di Era Merdeka Belajar. Al-Aufa: Jurnal Pendidikan Dan Kajian Keislaman, 2(1), 1-10.

Willems, J., Farley, H., \& Campbell, C. (2019). The Increasing Significance of Digital Equity in Higher Education: An Introduction to the Digital Equity Special Issue. Australasian Journal of Educational Technology, 35(6), 1-8. https://doi.org/https://doi.org/10.14742/ajet.5996

Wirartha, I. M. (2006). Pedoman Penulisan Usulan Penelitian, Skripsi \& Thesis. Andi. 